\title{
AOR
}

Selected Papers of \#AolR2019:

The $20^{\text {th }}$ Annual Conference of the Association of Internet Researchers Brisbane, Australia / 2-5 October 2019

\section{‘GLOBAL, NETWORKED AND COLLABORATIVE’': HOW THE NORMALIZATION OF LEAKING SHAPED THE IDENTITY AND PRACTICE OF INVESTIGATIVE JOURNALISM}

\author{
Stefan Baack \\ Weizenbaum Institute for the Networked Society \& Mozilla Foundation
}

From the Panama Papers to Pan-European investigations like the Migrants' Files², we appear to witness a "Golden Age of global muckraking" (Coronel 2016). This 'Golden Age' is driven by nonprofit organizations like the International Consortium of Investigative Journalists (ICIJ) that facilitate the collaboration between journalists from different countries. The resulting transnational journalism networks of today differ significantly from cross-national collaborations among journalists in the past. First, data technologies have dramatically increased their scale and degree of collaboration in recent years. Transnational collaborations among journalists are increasingly datadriven operations specialized on facilitating the analysis of huge data leaks (cf.

Sambrook 2018). Second, the media landscape in which transnational networks operate is much more dynamic. New types of media organizations, e.g. nonprofits like ProPublica or venture-baked startups like BuzzFeed, challenge traditional notions of journalism and make the field more inclusive and diverse. By pioneering the use of data to enable investigations on ever-growing scales within a more diverse field, transnational networks help to articulate common, global standards of journalistic practices and values and shape journalism's ability to tackle issues in an increasingly globalized and interdependent world.

I will show how debates about Wikileaks' role in relation to journalism, and especially its claim to 'be' journalism, let news media to adopt some of the technologies and practices it introduced. The normalization of leaking by journalists took place at a technological, an organizational, and a cultural level. Technologically, journalists have adopted encryption technologies and embraced whistleblower submission systems.

\footnotetext{
${ }^{1}$ Hume and Abbott (2017).

${ }^{2} \mathrm{http}: / /$ www.themigrantsfiles.com/.

Suggested Citation (APA): Baack, S. (2019, October 2-5). Global, Networked and Collaborative"1: How The Normalization Of Leaking Shaped The Identity And Practice Of Investigative Journalism. Paper presented at AolR 2019: The $20^{\text {th }}$ Annual Conference of the Association of Internet Researchers. Brisbane, Australia: AolR. Retrieved from http://spir.aoir.org.
} 
Organizationally, the normalization of leaking helped to create - or transform - national and transnational structures that facilitate collaborations across newsrooms. The organization in charge of the network primarily grants (exclusive) access to the leaked data to selected journalists and provides tools for collaborative data analysis. The most important normalization took place on the cultural level. Here, journalists moved the concept of leaking away from radical transparency advocacy, and into traditional journalistic ethics and identities by emphasizing 'responsible', partial disclosure. This way, they established a 'journalistic model' of leaking that is designed to gain trust in several ways. First, journalists seek to present themselves to potential whistleblowers as trustworthy receivers of leaked materials that will expose wrongdoings without causing unnecessary harm. Second, by combining responsible disclosure with a coordinated and simultaneous publication, journalists present themselves to the public as responsible and effective gatekeepers of publicly relevant information whose coverage gain broad, international attention.

The normalization of leaking is relevant beyond leaking itself, as it more broadly shaped practices around 'data-driven cross-border collaboration'. This means that the practices, organizational structures and technologies developed around leaking also shape collaborative data collection or data sharing projects like the aforementioned Migrants' Files, where journalists in 15 European countries collaboratively collected data documenting how many people died in their attempt to reach or stay in Europe. Therefore, the ways in which leaking has been normalized is more broadly connected to advances in data journalism and automation, and it helped to foster a culture of collaboration and sharing among investigative journalists. In sum, it fundamentally affected the shape of transnational networks of investigative journalists today.

The findings presented in this paper are connected to, and expand research on entrepreneurial forms of journalism and global journalism. First, it shows that parallel to the increased diversity of media organizations and ways of 'doing journalism' around news startups or nonprofit newsrooms, new forms of stabilizing and, to some extent, standardizing journalism practices have emerged. Second, it adds to empirical research that examines how global journalism manifests in the practices and identities of journalists (cf. Lindell and Karlsson 2016; Heikkilä and Kunelius 2006; Hepp et al. 2016) by showing how such practices have evolved around the normalization of leaking. To examine the future of journalism in a more globalized and datafied world, I will conclude with suggesting that media and journalism studies needs to rely more on theories and methodological frameworks that do justice to journalism's increasingly transcultural nature.

\section{References}

Coronel, Sheila. 2016. "Coronel: A Golden Age of Global Muckraking at Hand." Global Investigative Journalism Network. https://gijn.org/2016/06/20/a-golden-age-of-globalmuckraking/.

Heikkilä, Heikki, and Risto Kunelius. 2006. "Journalists Imagining the European Public Sphere.” Javnost - the Public 13 (4): 63-79. https://doi.org/10.1080/13183222.2006.11008925. 
Hepp, Andreas, Monika Elsler, Swantje Lingenberg, Anne Mollen, Johanna Möller, and Anke Offerhaus. 2016. The Communicative Construction of Europe: Cultures of Political Discourse, Public Sphere, and the Euro Crisis. Transformations of the State. London: Palgrave Macmillan.

Hume, Ellen, and Susan Abbott. 2017. "The Future of Investigative Journalism: Global, Networked and Collaborative," 29.

https://cmds.ceu.edu/sites/cmcs.ceu.hu/files/attachment/article/1129/humeinvestigativej ournalismsurvey $0 . p d f$.

Lindell, Johan, and Michael Karlsson. 2016. "Cosmopolitan Journalists?" Journalism Studies 17 (7): 860-70. https://doi.org/10.1080/1461670X.2016.1165137.

Sambrook, Richard, ed. 2018. Global Teamwork: The Rise of Collaboration in Investigative Journalism. Oxford: Reuters Institute for the Study of Journalism. https://reutersinstitute.politics.ox.ac.uk/sites/default/files/2018-03/sambrook eISBN 1802.pdf. 